\title{
Evaluation of Different Management Modules for Leaf Curl Disease of Chilli in Kymore Plateau and Satpura Hill Zone of Madhya Pradesh, India
}

\author{
Jai Singh $^{1}$, Geeta Sharma ${ }^{2 *}$, A.K. Chaubey ${ }^{1}$ and M.S. Baghel ${ }^{1}$ \\ ${ }^{1}$ J.N.K.V.V., Krishi Vigyan Kendra, Sidhi-486661 (M.P.), India \\ ${ }^{2}$ Department of Plant Pathology, G.B.P.U.A.\&T., Pant nagar, U.S.Nagar-263145, \\ (Uttaranchal), India \\ *Corresponding author
}

\section{A B S T R A C T}

Two year On Farm Trial (OFT) was conducted in 27 locations holding of Chorgarhi and Jhalwar village of District Sidhi in Madhya Pradesh during kharif, 2012-13 and 2013-14. In order to assess the efficacy of four different integrated management modules for the

\section{Keywords}

Chilli, Leaf curl, Integrated disease management, On farm trial

Article Info

Accepted: 20 December 2017 Available Online: 10 January 2018 management of leaf curl disease of Chilli. The experimental findings revealed that all the management modules were found superior over farmer's practice. The module $T_{4}$ having Seed treatment with thiomethxam-70WS @ $5 \mathrm{~g} / \mathrm{kg}$ seed +seedling treatment with imidachloprid-17.8SL @ 3.0ml/10 lit. for $30 \mathrm{~min}+$ two weeding + two sprays of neem oil @ $1 \%$ at 30 and $60 \mathrm{DAT}+$ imidachloprid-17.8SL @ 125ml/ha at $45 \mathrm{DAT}+$ thiomethaxam @ $100 \mathrm{~g} / \mathrm{ha}$ at 75 DAT was found most effective in reducing disease incidence about $86 \%$ as well as total number of insect-vector/ plant (94.44 to $96.36 \%$ ) and similarly increases green chilli yield ( 47.81 to $53.76 \mathrm{q} / \mathrm{ha})$ and cost benefit ratio (5.91:1 to 5.92:1) over control followed by module $T_{3}$ (Seed treatment with imidacloprid-70WS @ 10g/kg + one spray of neem oil @ 1\% at 30 DAT + two spray of imidacloprid-17.8 SL @ $125 \mathrm{ml} / \mathrm{ha}$ at 45 and 60 DAT.) and $\mathrm{T}_{2}$ (Seed treatment with Raw Cow's Milk (RCM) for 24 hours in 1:1 ratio (i.e. RCM diluted to $50 \%$ by adding water) + dipping of seedlings in $15 \%$ RCM for 20 minutes + two sprays of 15\% RCM at 30 and 60 DAT one spray of dimethoate -30EC@ 1.0 lit./ha at 45 DAT). Thus, on the basis of the data, it is concluded that module T4 and T3 may be considered for improved sustainable management of leaf curl disease of chilli.

\section{Introduction}

Chilli (Capsicum annum L.) is an important cash crop of India. Besides traditional use of chilli as vegetables, spices, condiments, sauces and pickles, it is also used in pharmaceuticals, cosmetic and beverages (Tiwari et al., 2005). Chilli has very excellent nutritive value especially for vitamin A and C. Each 100 gram chilli contains 160 calorie energy, 36 gram carbohydrates, 16 gram proteins, 480 milligram fat, $3.1 \mathrm{mg}$ calcium, $640 \mathrm{IU}$ vitamin $\mathrm{A}$ and $40 \mathrm{mg}$ vitamin C (Narayanan et al., 1999). The major chilli producing countries in the world are China, Turkey, Mexico, Spain, USA, Indonesia, Nigeria, Egypt, Korea, Italy and India. In India chillies are grown in 794.1 million ha area with 1304.4 million tonnes production and $1643 \mathrm{Kg} / \mathrm{ha}$ green chilli yield during 2012-13. Madhya Pradesh is one of the 
chilli producing states in India. Out of several factors responsible for low productivity of chilli, chilli leaf curl disease is one of the major limiting factors for cultivation of crop in Madhya Pradesh. It is most cosmopolitan problem causing average annual yield loss of 34.14 per cent (Ahmad et al., 1987) however, in epidemic conditions the yield loss may exceed up to 100 per cent (Senanayake et al., 2006). The susceptibility of popular cultivars against leaf curl disease is the main reason for the severity of the diseases and thus affecting the productivity of the chilli crop in the state.

Chilli leaf curl disease is a viral disease which appears as severe leaf curl with cup - shaped, upward curling of leaves and stunted plant growth. Senanayake et al., (2006) reported that chilli leaf curl disease caused by begomoviruse (CLCV) was transmitted by white fly (Bemisia tobacci).

In order to reduce the disease severity, a number of insecticides were tried for reducing the population of these insect vectors, out of which, Rathod et al., (2010) showed that Imidacloprid 70 WS @ $5 \mathrm{~g} / \mathrm{kg}$ of seed was most effective followed by Imidacloprid 200 SL @ $0.5 \mathrm{ml} / 1$ at 20 and 30 days after emergence in minimizing average population of whiteflies. However, Zhang et al., (2011) reported Imidacloprid and Thiamethoxam to be the most effective in controlling $B$. tabaci under lab conditions and also in field when used as a seed treatment method. whitefly population as well as yellow mosaic virus incidence were less in Diafenthiuron $50 \mathrm{WP}$ @ $600 \mathrm{~g} / \mathrm{ha}$, Imidacloprid 70 WG @ $75 \mathrm{~g} / \mathrm{ha}$ and Thiamethoxam 25 WG @ 100 g/ha treatments compared to the untreated control (Gopalaswamy et al., 2012).

Farmers are extensively using these insecticides singly or in combination to protect such a high valued crop from any type of damage caused by various insect pests, however, they failed to minimize the losses. They often indiscriminately use huge amount of insecticides which lead resurgence of pests, phyto-toxicity of fruits, destruction of earthworms, poor fruit setting due to killing of pollinators and other health hazards (Sridhar et al., 2014). Nimbalkar et al., (1993) and Rashid et al., (2012) who reported that neem oil significantly reduced the white fly population in cotton. In this regard, some novel pesticides from natural origin were used to develop and follow a rational approach to develop effective and eco-friendly Integrated Disease Management Modules (IDMs) for sustainable production of chilli crop.

\section{Materials and Methods}

\section{Field survey}

During the year 2012-13, surveys were conducted for the presence of leaf curl disease of chilli in 8 different villages viz., Chorgarhi, Jhalwar, Upani, Panwar, Tala, Kushmi, Padaria and Hatwakhas with varying latitudes and longitudes (Table 2) in three different field were chosen from each villages of five different blocks of Sidhi District in Madhya Pradesh during the months of July- August In the each visited field three plot of size $3 \times 3$ meter were selected to observe overall disease incidence on visual symptoms. Data were recorded on disease incidence (\%) by counting total number of plant as well as diseased plant. Per cent disease incidence was calculated by following formula.

No. of diseased plants

Disease Incidence $(\%)=$-------------- x 100

Total no. of assessed plants (Nene, 1972)

\section{Field experiment}

The field experiment were conducted during Kharif season of 2012-13 and 2013-14 at 27 farmer's fields of Chorgarhi, Jhalwar and 
Upani Villages of Sidhi District by Krishi Vigyan Kendra, Sidhi (MP) to find out efficacy of different integrated disease management modules against leaf curl disease of chilli under the On Farm Trial (OFT) activity of KVK. The trials were laid out in completely randomized block design having four treatments including control (farmers practice) maintaining 10 replications (Table 1). The experimental field was prepared by ploughing thrice with cultivator followed by planking for fine tilt and smooth surface. Recommended dose of FYM (1 t/ha) was mixed in soil 30 days before transplanting and recommended dose of fertilizers (100:50:50 $\mathrm{kg} \mathrm{NPK/ha)} \mathrm{was} \mathrm{applied} \mathrm{at} \mathrm{the} \mathrm{time} \mathrm{of}$ transplanting. Thirty days old seedlings of variety VNR-305, raised under insect proof conditions were transplanted at $60 \times 45 \mathrm{~cm}$ spacing. Standard agronomic practices were followed to grow the crop.

Incidence of the disease was recorded by taking counts of twenty randomly selected and tagged plants, leaving the borders, seven days after imposing the treatment. Percent disease incidence and reduction in disease incidence were calculated by following formula.

No. of diseased plants

Disease Incidence (\%) = ---------------- x 100

Total no. of assessed plants

Disease incidence in untreated plots Reduction in disease incidence $(\%)=---\mathrm{x} 100$

Disease incidence in treated plots (Nene, 1972)

\section{Estimation of vector population}

The method given by Bhattiprolu and Rahman (2006) was used to monitor white fly population in the field. According to which, five plants per treatment and three terminal leaves per plant were randomly selected and tagged. White fly populations were recorded directly on leaves early in the morning when they were less active. Observations were recorded at seven days interval starting from 14 days after transplanting (DAT) till last harvesting of fruits.

\section{Yield and yield component}

Fruit yield of each plot and number of fruit/ plant were taken separately for each module and calculated by cumulating the successive plucking from respective field and then converted to quintal per hectare. The data were tabulated, pooled and ranked on the basis of their yield performance. Per cent yield increase and Per cent increase no. of fruit per plant were calculated as given below;

$\%$ Increase in yield $=[\{$ Yield in Treated plot Yield in untreated plot $\left.\left(T_{1}\right)\right\} /$ yield in $\left.T_{1}\right] \mathrm{x}$ 100

$\%$ Increase number of fruit $/$ plant $=[\{$ no. of fruit in Treated plot - no. of fruit in untreated Plot $\left.\left(T_{1}\right)\right\} /$ no. of fruit in $T_{1}$ ] x 100

\section{Estimation of cost-benefit ratio}

The Cost Benefit Ratio (CBR) of different modules was calculated by estimating cost of cultivation and gross income received from the produce per hectare land.

Average market price of green chilli was Rs. 10.00 per kg during experimental period. Cost benefit ratio was calculated by using following formula:

\section{Gross income

$$
\text { CBR = - }
$$

The field data were analyzed in Randomized Block Design by $\mathrm{F}$ test for significance and critical difference of values were calculated at 5 per cent significance level. 


\section{Results and Discussion}

\section{Field survey}

Roving survey of major chilli growing areas of Sidhi district under Kymore Plateau and Satpura Hills Agroclimatic Zone of Madhya Pradesh conducted during 2012-13 revealed wide range of leaf curl symptoms in addition to vein clearing, puckering, crinkling and stunting of the plants. Incidence of leaf curl incidence was varied from 5 to 81 per cent (Table 2). The maximum average incidence of leaf curl was recorded in Panwar village (58.66 \%) followed by Chorgarhi (53.33\%) however, minimum in Tamsar $(31.33 \%)$. The present finds are in accordance with the observation of Ahmad et al., (2014) who reported that disease incidence of chilli leaf curl varied from 11 to 64 per cent in different zone of Punjab with varied in almost all varieties / hybrids grown in this tract were susceptible to chilli leaf curl complex. Though the disease incidence varied with the cultivar, Variation of leaf curl incidence within the hybrids / varieties is due to the different management practise applied by the farmers.

\section{Field experiment}

\section{Disease incidence}

The impact of different IDMs on the severity of leaf curl disease and population of white flies and mite in chilli were recorded. The data presented in Table 3 revealed that all the treatments caused significant reduction in disease incidence and population of whitefly. Lowest leaf curl disease incidence was recorded in the treatment $\mathrm{T}_{4}$ receiving Seed treatment with thiomethxam-70WS @ 5 g/ kg seed +seedling treatment with imidachloprid17.8SL@3.0ml/10 lit. for $30 \mathrm{~min}+$ two weeding + two sprays of neem oil @1\% at 30 and 60 DAT + imidachloprid-17.8SL @ 125 $\mathrm{ml} / \mathrm{ha}$ at $45 \mathrm{DAT}+$ thiomethaxam@125 g /ha at 75 DAT followed by the treatments $\mathrm{T}_{3}$ where Seed treatment with imidacloprid70WS@10g/kg + one spray of neem oil @ $1 \%$ at 30 DAT + two spray of imidacloprid$17.8 \mathrm{SL} @ 125 \mathrm{ml} / \mathrm{ha}$ at 45 and 60 DAT was done and then in treatment $\mathrm{T}_{2}$ (Seed treatment with Raw Cow's Milk (RCM) for 24 hours in 1:1 ratio (i.e. RCM diluted to $50 \%$ by adding water) + dipping of seedlings in 15\% RCM for 20 minutes + two sprays of $15 \%$ RCM at 30 and 60 DAT one spray of dimethoate-30EC@ 1.0 lit./ha at 45 DAT). The highest disease incidence was recorded in $\mathrm{T}_{1}$ (Control treatment) which is the usual practice done by the farmers. The leaf curl disease incidence was found varied from 9.4 to 72.4 per cent depending on the IDM modules. Kumar and Kumar (2017) are also found that integrated disease management module (Resistant variety + seed treatment with Thiomethoxam 70 WS @ $3 \mathrm{gm} / \mathrm{kg}+$ Soil application of corbofuron @ $15 \mathrm{~kg} / \mathrm{ha}$ during transplanting of seedlings+ planting of maize as a barrier crop + roughing out of infected plants at initial stage of infection+ 2-3 spray of systemic insecticides before flowering) for leaf curl in chilli reduced $52.53 \%$ to $56.70 \%$ disease incidence over farmers practice.

\section{Estimation of vector population}

The present findings also revealed that lower population of white flies ( 0.4 to $0.6 /$ three terminal leaves) were found in the treatment $\mathrm{T}_{4}$ followed by the treatment $\mathrm{T}_{3}$ and $\mathrm{T}_{2}$. The crop in control harboured significantly higher population of white flies in both the years (Table 3). The results of this study are nearly similar to the reports of Gopalaswamy et al., (2012), Rathod et al., (2010) and Zhang et al., (2011) who reported that imidachloprid and thiamethoxam to be the most effective in controlling B. Tabaci. Nimbalkar et al., (1993) conclude that neem oil reduces infestations of whitefly eggs and adults in the greenhouse when used in the second application. 
Table.1 Details of different Integrated Disease Management Modules (IDMs) in chilli

\begin{tabular}{|c|c|c|}
\hline Sl. No. & IDMs & Details \\
\hline 1 & $\mathrm{~T}_{1}$ & Control \\
\hline 2 & $\mathrm{~T}_{2}$ & $\begin{array}{l}\text { Seed treatment with Raw Cow's Milk (RCM) for } 24 \text { hours in } 1: 1 \text { ratio (i.e. RCM } \\
\text { diluted to } 50 \% \text { by adding water) + dipping of seedlings in } 15 \% \text { RCM for } 20 \text { minutes } \\
+ \text { two sprays of } 15 \% \text { RCM at } 30 \text { and } 60 \text { DAT one spray of dimethoate -30EC@ } 1.0 \\
\text { lit./ha at } 45 \text { DAT. }\end{array}$ \\
\hline 3 & $\mathrm{~T}_{3}$ & $\begin{array}{l}\text { Seed treatment with imidacloprid-70WS @ } 10 \mathrm{~g} / \mathrm{kg}+\text { one spray of neem oil @ } 1 \% \text { at } \\
30 \mathrm{DAT}+\text { two spray of imidacloprid-17.8 SL @ } 125 \mathrm{ml} / \mathrm{ha} \text { at } 45 \text { and } 60 \mathrm{DAT} \text {. }\end{array}$ \\
\hline 4 & $\mathrm{~T}_{4}$ & $\begin{array}{l}\text { Seed treatment with thiomethxam-70WS @ } 5 \mathrm{~g} / \mathrm{kg} \text { seed +seedling treatment with } \\
\text { imidachloprid-17.8SL @ 3.0ml/10 lit. for } 30 \mathrm{~min}+\text { two weeding }+ \text { two sprays of } \\
\text { neem oil @ } 1 \% \text { at } 30 \text { and } 60 \mathrm{DAT}+\text { imidachloprid-17.8SL @ } 125 \mathrm{ml} / \mathrm{ha} \text { at } 45 \text { DAT } \\
+ \text { thiomethaxam @ } 125 \mathrm{~g} / \mathrm{ha} \text { at } 75 \mathrm{DAT} \text {. }\end{array}$ \\
\hline
\end{tabular}

Table.2 Incidence of leaf curl of chilli in different blocks of Sidhi District of Madhya Pradesh

\begin{tabular}{|c|c|c|c|c|c|c|}
\hline \multirow[t]{3}{*}{ Locations } & \multirow[t]{3}{*}{ Blocks } & \multirow[t]{3}{*}{ Variety } & \multicolumn{2}{|c|}{ GPS Location } & \multicolumn{2}{|c|}{ Disease Incidence (\%) } \\
\hline & & & \multirow[t]{2}{*}{ Latitude } & \multirow[t]{2}{*}{ Longitude } & & \\
\hline & & & & & Range & Average \\
\hline Chorgarhi & Rampur Naikin & VNR-305 & $24^{0} 18^{\prime} 53.3$ & $81^{0} 24^{\prime} 40.5$ & 49- 59 & 53.33 \\
\hline Jhalwar & Rampur Naikin & VNR 314 & $24^{0} 24^{\prime} 1.8$ & $81^{0} 34^{\prime} 34.3$ & $27-68$ & 49.66 \\
\hline Upani & Sidhi & Pant C-1 & $24^{0} 24^{\prime} 24.8$ & $81^{0} 57^{\prime} 23.8$ & $13-60$ & 41.0 \\
\hline Panwar & Sidhi & VNR-305 & $24^{0} 23^{\prime} 53.0$ & $81^{0} 50 ’ 34.5$ & $5-81$ & 58.66 \\
\hline Padaria & Sihawal & NS-668 & $24^{0} 26^{\prime} 6.4^{\prime \prime}$ & $82^{0} 06^{\prime} 57.0$ & $17-62$ & 51.33 \\
\hline $\begin{array}{l}\text { Hatwa } \\
\text { khas }\end{array}$ & Sihawal & Garima & $24^{0} 33^{\prime} 5.9$ & $81^{0} 07^{\prime} 32.4$ & $6-76$ & 42.0 \\
\hline Madwas & Majhauli & Roshani & $24^{0} 10^{\prime} 06.3$ & $81^{0} 51^{\prime} 35.1$ & $31-70$ & 49.0 \\
\hline Tamsar & Kushmi & VNR-305 & $24^{0} 12^{\prime} 01.3$ & $81^{0} 50^{\prime} 49.5$ & $8-75$ & 31.33 \\
\hline
\end{tabular}

Table.3 Effect of IDMs on leaf curl disease incidence and population of insect- vector

\begin{tabular}{|c|c|c|c|c|c|c|c|c|}
\hline \multirow[t]{2}{*}{$\begin{array}{c}\text { Treatme } \\
\text { nt }\end{array}$} & \multicolumn{2}{|c|}{$\begin{array}{c}\text { Disease } \\
\text { Incidence }(\%)\end{array}$} & \multicolumn{2}{|c|}{$\begin{array}{l}\text { Percent disease } \\
\text { decrease over } \\
\text { control (T1) }\end{array}$} & \multicolumn{2}{|c|}{$\begin{array}{l}\text { White fly Population } \\
\text { ((no. white fly / three } \\
\text { terminal leaves) }\end{array}$} & \multicolumn{2}{|c|}{$\begin{array}{l}\% \text { reduction in } \\
\text { White fly population } \\
\text { (no. white fly / three } \\
\text { terminal leaves) }\end{array}$} \\
\hline & $\begin{array}{c}2012- \\
13\end{array}$ & $\begin{array}{c}2013- \\
14\end{array}$ & $\begin{array}{c}2012- \\
13\end{array}$ & 2013-14 & 2012-13 & 2013-14 & $\begin{array}{c}2012- \\
13\end{array}$ & 2013-14 \\
\hline $\mathrm{T} 1$ & 68.5 & 72.4 & - & - & 11 & 10.8 & - & - \\
\hline $\mathbf{T 2}$ & 28.6 & 28.6 & 58.24 & 60.49 & 4.8 & 5.2 & 56.36 & 51.85 \\
\hline T3 & 18.2 & 17.2 & 73.43 & 76.24 & 1.6 & 1.8 & 85.45 & 83.33 \\
\hline $\mathrm{T4}$ & 9.4 & 10 & 86.27 & 86.18 & 0.4 & 0.6 & 96.36 & 94.44 \\
\hline $\begin{array}{l}\text { CD at } \\
5 \%\end{array}$ & 4.15 & 3.60 & - & - & 1.24 & 0.88 & - & - \\
\hline
\end{tabular}


Table.4 Effect of IDMs on yield and yield components of chilli

\begin{tabular}{|c|c|c|c|c|c|c|c|c|}
\hline \multirow[t]{2}{*}{ Treatments } & \multicolumn{2}{|c|}{$\begin{array}{l}\text { Yield of green } \\
\text { chilli (q/ha) }\end{array}$} & \multicolumn{2}{|c|}{$\begin{array}{l}\text { Yield increase over } \\
\text { control }(\%)\end{array}$} & \multicolumn{2}{|c|}{ No. of fruits/ plant } & \multicolumn{2}{|c|}{$\begin{array}{l}\text { Percent increase in } \\
\text { no. of fruits over } \\
\text { control }\end{array}$} \\
\hline & $2012-13$ & 2013-14 & $2012-13$ & 2013-14 & $2012-13$ & 2013-14 & $2012-13$ & 2013-14 \\
\hline T1 & 106.74 & 107.54 & - & 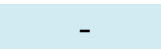 & 69.2 & 69.6 & - & - \\
\hline $\mathrm{T2}$ & 140.88 & 141.78 & 31.98 & 34.32 & 86.6 & 87.8 & 25.14 & 23.27 \\
\hline T3 & 154.52 & 156.16 & 44.76 & 45.21 & 96.8 & 98 & 39.88 & 40.48 \\
\hline $\mathrm{T4}$ & 160.5 & 163.96 & 50.36 & 52.46 & 102.2 & 103.8 & 47.68 & 49.13 \\
\hline CD at $5 \%$ & 8.70 & 9.45 & - & - & 9.91 & 7.24 & - & - \\
\hline
\end{tabular}

Table.5 Economics of different IDMs in chilli

\begin{tabular}{|c|c|c|c|c|c|c|c|c|}
\hline \multirow{2}{*}{ Treatments } & $\begin{array}{c}\text { Cost of cultivation } \\
\text { (Rs./ha) }\end{array}$ & \multicolumn{2}{c|}{$\begin{array}{c}\text { Gross income } \\
\text { (Rs./ha) }\end{array}$} & \multicolumn{2}{c|}{ Net income (Rs./ha) } & \multicolumn{2}{c|}{$\begin{array}{c}\text { Cost benefit ratio } \\
\text { (CBR) }\end{array}$} \\
\cline { 2 - 11 } & $2012-13$ & $2013-14$ & $2012-13$ & $2013-14$ & $2012-13$ & $2013-14$ & $2012-13$ & $2013-14$ \\
\hline T1 & 20169.50 & 20372.00 & 106740.0 & 107540.0 & 86570.50 & 87168.0 & 5.29 & 5.27 \\
\hline T2 & 25456.00 & 26076.80 & 140880.0 & 141780.0 & 115424.00 & 115703.20 & 5.53 & 5.44 \\
\hline T3 & 26605.40 & 27009.00 & 154520.0 & 156160.0 & 128014.60 & 129151.00 & 5.80 & 5.78 \\
\hline T4 & 27137.20 & 27510.20 & 160500.0 & 163000.0 & 133362.80 & 135489.70 & 5.91 & 5.92 \\
\hline
\end{tabular}

\section{Yield and yield component}

The results depicted in Table 4 clearly indicates that significantly highest yield of green chilli was recorded in the treatment T4 (160.5 and 163.0 q/ ha in 2012-13 and 2013-14, respectively) followed by $\mathrm{T} 3$ (154.52 and $156.16 \mathrm{q} / \mathrm{ha}$, respectively, in both the years) and other treatments.

Number of fruits/plant were also higher (102.2 and 103.8 fruits/plant in the year 2012-13 and 2013-14, respectively) in treatment $\mathrm{T}_{4}$ followed by T3 (96.8 and 98.8 fruits/ plant in 2012-13 and 2013-14, respectively).

Whereas the lowest number of fruits per plant (69.2 and 69.6 in the year 2012-13 and 2013-14, respectively) were recorded in control plot $\left(T_{1}\right)$. The results of this study are nearly similar to the reports of Kumar and Kumar (2017) who reported that integrated leaf curl management module resulted enhance the average productivity were ranges from $18.28 \%$ to 20.73 $\%$ over farmers practice.

\section{Estimation of cost-benefit ratio}

The economics was also calculated after the experimentation based on the expenditure incurred for different IDMs imposed and the income from the yield of green chilli and the data are presented in Table 5.

The maximum net profit of Rs. 135489.70 to 133362.80/ ha was obtained from treatment $\mathrm{T}_{4}$ followed by $\mathrm{T}_{3}$ (Rs. 129151.00 to $128014.60 /$ ha) which is significantly higher than the usual practice done by the farmers of the area. The above finding also certifies the work done by the earlier worker Kumar and Kumar (2017).

On the basis of the observations and the data collected during the experimentation, it could be very well understood that there is a very important role of the insects as disease transmitting vectors on the incidence of leaf curl disease of chilli but it could be reduced by applying integrated package of practices not only for the disease or insect management but 
also for the overall health of the plants during the crop growth period starting from the field preparation to the nursery management till final harvest. The development and application of integrated disease management modules is the need of the hour through which not only the higher yield of the crop but also sustainability of the soil health and environment could be achieved.

\section{References}

Ahmad, I.A., Sharma, A. and Kang, S.S. 2014. Prevalence of chilli leaf curl disease in Punjab. Plant Disease Research, 29(1): 75-79.

Ahmed K, Mohammed GM and Murthy NSR 1987. Yield loss due to pests in hot pepper. Caps. Newslet, 6: 83-84

Bhattiprolu SL and Rahman MA 2006. Management of Insect Borne Viral Diseases of Chilli Using Nylon Net, Chemicals, Neem Products and Barrier. Crop J. Agric. Sci., 19 (1), 154-157.

Gopalaswamy S V S, Ramana M V and Krishna Y R 2012. Management of YMV of blackgram by chemical control of Bemisia tabaci Gennadius. Ann. Pl. Protec. Sci., 20: 358-60.

Kumar, U and Kumar, S. 2017. IDM module for the management of leaf curl disease in chilli. Int.J.Curr.Microbiol. App. Sci., 6(9): 2087-2091.

Narayanan SS, Hedge S, Sadananda AR and Chelliah S 1999. Commerce and utility considerations of chillies. Kisan World. 26(9): 73-75

Nene YL 1972. A survey of viral diseases of pulse crops in Uttar Pradesh. G.B. Pant. Univ. Agric. Technol. Pantnagar Res.
Bull., 4, 911.

Nimbalkar SA, Khodke SM, Taley YM, Patil KJ. 1993. Bioefficacy of some new insecticides including neem seed extract and neem oil for controlling whitefly on cotton. Botanical Pesticides in Integrated Pest Management, 256-260.

Rashid MM, Khattak MK, Abdullah K. 2012. Evaluation of Botanical and Synthetic Insecticides for the management of Cotton Pest Insects. Pak. J. Zool., 44(5):1317-1324.

Rathod P K, Mane P N, Thakre A N, Deshmukh S N and Barkhade U P 2010. Management of whitefly, Bemisia tabaci and thrips, Scirtothrips dorsalis in rabi sunflower with botanicals and chemicals. Indian J Pl Protec 38: 139-43.

Senanayake DMJB, Mandal B, Lodha S, Varma A, 2006. First report of Chilli leaf curl virus affecting chilli in India. New Disease Reports 13 [http://www. ndrs.org.uk/july2006/2006-35.asp].

Sridhar, K., Rajesh, V. and Omprakash, S. 2014. A critical review on agronomic management of pests and diseases in chilli. Internat. J. Plant, Animal \& Environ. Sci., 4 (1): 284-289.

Tiwari A, Kaushik MP, Pandey KS and Dangy RS 2005. Adoptability and production of hottest chilli variety under Gwalior agroclimatic conditions. Current Science, 88(10): 1545-1546.

Zhang L, Greenberg S M, Zhang Y and Liu T X 2010. Effectiveness of Thiamethoxam and Imdicloprid seed trestments against Bemisia tabaci (Hemiptera: Aleoyrodidae) on cotton. Pest Manag. Sci 67: 226-32.

\section{How to cite this article:}

Jai Singh, Geeta Sharma, A.K. Chaubey and Baghel, M.S. 2018. Evaluation of Different Management Modules for Leaf Curl Disease of Chilli in Kymore Plateau and Satpura Hill Zone of Madhya Pradesh, India. Int.J.Curr.Microbiol.App.Sci. 7(01): 2544-2550.

doi: https://doi.org/10.20546/ijcmas.2018.701.306 